\title{
A Study on the Application of Task-Based Language Teaching Approach in English Listening Class for College English Major in China
}

\begin{abstract}
Xiaohui Sun ${ }^{1 *}$
${ }^{1}$ Xiaohui Sun Shandong Management University
${ }^{*}$ Corresponding author. Email: sunxiaohui94@hotmail.com

ABSTRACT

Task-based language teaching has been strongly advocated and recommended by many linguists in English language teaching. This study examines the effects of the application of TBLT in English listening classes for 80 college English majors in mainland China. A quantitative questionnaire was used to investigate after a semester of listening study. The results showed that students could improve their English listening ability with the instruction of TBLT. Also, their motivation could be activated and they became more active in class and after class. Additionally, they could also develop their other competencies such as communication skills. In the end, more research needs to be investigated further.
\end{abstract}

Keywords: Task-based Teaching Method, College English Major, Listening, Application Research.

\section{INTRODUCTION}

Audio-visual English class is one of the most essential classes for students from college English major in China, intending to improve student's English skills of listening competence. However, it has gained less attention than other language skills such as reading and writing from the perspective of pedagogy even for the students from English majors. Compared with traditional second language teaching, Task-based Language Teaching (TBLT) provides a new perspective for second language teaching, and has drawn a lot of attention in recent years. Meanwhile, it has gradually been adopted by English teachers in China, especially in reading and grammar classes. Some researchers have done studies on applying TBLT in university English classes for non-English major, however, investigating the application of TBLT for students from English major are still needed, especially in listening classes. Therefore, this research focuses on the application of TBLT in listening class for English majors and the effectiveness of this teaching instruction. It is hoped that this study is of great significance for the research of second language acquisition and foreign language teaching.

\subsection{A Review of Previous Studies and Theories}

\subsubsection{Definition of Task-based Language Teaching}

Task-based Language Teaching (TBLT) is a kind of communicative teaching method applied in the teaching process of a foreign language. It was put forward in the 1980s and first applied by Prabu [1] in the Bangalore Project in India. After that, it has drawn much attention from researchers. Skehan [2] argued that learners were given tasks to complete in the classroom and in this way would the learners engage naturalistic acquisitional mechanisms. Compared with traditional instructional teaching, Richards and Rodgers [3] believed that TBLT could improve the learning process and create a better learning environment for language learners. Study of the target language let learners to soak themselves in input and put them in some tasks which need significant communication, so that effective output could be produced. In addition, features of TBLT are emphasized on meaningful learning, involvement in the real world process of language use, and engagement of cognitive process [4]. Jeon and Hahn [5] claimed that TBLT provided learners with natural sources of meaningful material, ideal situations for communicative activity, and supportive feedback for much greater opportunities 
to practice the language. According to Van den Branden [6] and Norris [7], task-based language assessment was a critical element in task-based language teaching. Furthermore, Nunan [8] argued that TBLT aimed to design the language courses in which the point of departure was not an ordered list of linguistic items, but a collection of tasks. It can also reflect the changing conceptions of language itself.

\subsubsection{Research on Task-based Language Teaching}

Research on TBLT can originate from the early $20^{\text {th }}$ century. N. S. Prabhu, an Indian language teaching specialist, is the first one to apply TBLT in his teaching practice. He carried out his Bangalore Project in Southern India and published his book named Second Language Pedagogy in 1987. In his book, he introduced his series of points of view about language teaching and learning. In addition, David Nunan is another best representative of TBLT. The book titled Designing Tasks for the Communicative Classroom announced: "a balanced introduction to both the practical and theoretical aspects of the design of communicative tasks" [9].

In mainland China, the Ministry of Education issued the English Curriculum Standards for Senior (Experiment Edition) and encouraged teachers to apply TBLT to cultivate students' comprehensive language competence. Since then, many scholars and researchers have been absorbed in the study of TBLT. They published plenty of articles and works from different aspects of TBLT. Zan Mao [10] explored the application of task-based language teaching to English reading classrooms for middle school students. Shijun Chen \& Jing Wang [11] investigated the effects of the TBLT approach and language assessment on undergraduate English major students' competencies in the intensive reading course and found that "TBLT applied in Chinese English teaching class is very effective and beneficial for the enhancement of Chinese English learners" [11]. Yilin Huang \& Sohani Gandhioke [12] claimed that with the application of TBLT, students enjoyed playing word games in the English class and could improve their language ability and building skills. They recommended teachers use TBLT in English vocabulary teaching and learning. Mu-Hsuan Chou [13] implemented TBLT to develop metacognitive strategies for listening comprehension and the participants in the research were students taking the English for General Academic Purposes (EGAP) courses in a university. However, the research did not focus on English majors. Danyan Huang [14] studied whether the application of TBLT in comprehensive English classes for English majors would foster students' motivation and language proficiency. Although the participants of her study are English majors, comprehensive English class is not completely listening class. Based on the previous research condition, studies on the application of listening classes for English majors are not adequate and need to be further investigated.

\subsection{Research Questions}

This study aims to answer the following questions:

a. Whether could TBLT improve English-major students' English listening skills?

b. How do students perceive the use of TBLT in the English listening course?

\section{METHODOLOGY}

\subsection{The Participants}

The study was carried out at one of the universities in Jinan, Shandong province, China. 80 mixed-sex sophomores from English majors attended this research and their ages range from 17 to 21 . All of them have the similar educational background and they have already studied English in the university for one year. In addition, all of them exhibited no audio-visual and speech problems.

\subsection{Instruments}

This research mainly adopted a quantitative approach in this empirical study and a tailored questionnaire survey was used in the study. The research was investigated before the end of the listening course in the semester.

Data were collected via the questionnaire sent out for the participants. The questionnaire was anonymous. A total of 80 valid questionnaires were collected. There are five sections in the questionnaire. The first section was about a survey of students' basic information such as grade, age, and gender, which may affect English listening learning. The second part was about students' interests, motivation, and attitudes towards the study of English listening. The third part investigated students' thoughts about English learning resources and the arrangement of classroom teaching activities. The last section asked student's perceptions about the teacher's task setting and whether these tasks would improve their listening skill. The last part was an open question, which mainly collected students' suggestions on English listening teaching and the improvement of the TBLT classroom.

In addition, a Likert Scale was adopted in the questionnaire survey and 1 representing "strongly disagree", 2 representing "disagree", 3 representing "moderate", 4 representing "agree" and 5 representing "strongly agree". After students finished their questionnaire, points were given aromatically and 
accordingly. The higher overall score may indicate that the students may prefer TBLT pedagogically and improve their listening proficiency to a large extent.

\section{RESULTS AND DISCUSSION}

After the questionnaires were completed and collected, the data were calculated and analyzed. In section two of the questionnaire, the fourth question is about the reason why students study English listening courses, which aims to research students' motivation for listening. The chosen items, the number of each item the students choose, and the percentage are in Figure 1.

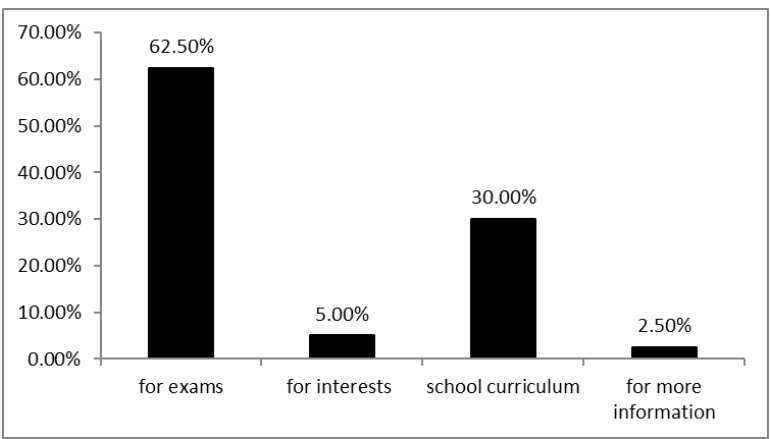

Figure 1 Distribution of the Reason of Studying Listening

To most people, the motivation for studying an English course is to pass exams. Only $7.5 \%$ of students are studying English courses to get information and develop interests and hobbies. The reason for this distribution is that the education evaluation system in China is test-oriented and many students take academic achievement seriously.

In section three, the tenth question is "which kinds of arrangement of classroom teaching activities let you improve your listening capacity?" The chosen items, the number of each item the students choose, and the percentage are in Figure 2.

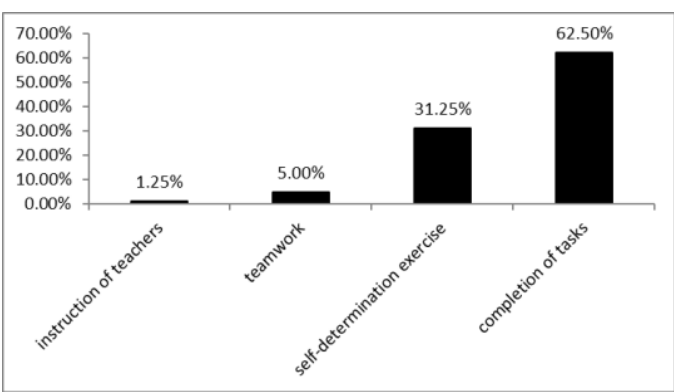

Figure 2 Distribution of Kinds of Arrangement of Classroom Teaching Activities

According to Figure 2, 62.5\% of students believed that they improved their listening ability by finishing the tasks that the teacher designed in class. It was found that over half of the students had a positive attitude towards TBLT and recognized this kind of pedagogy.
In section four, according to the collected data, $66.25 \%$ of students agreed that the way they did tasks helped them learn a lot. 10\% of students strongly agreed that they could learn a lot via TBLT. The results showed that a majority of students could gain more knowledge and TBLT could create a better environment to facilitate their learning process during the class. The chosen items, the number of each item the students choose, and the percentage in the thirteenth question are in Table 1.

Table 1. "The way I did tasks really helped me learn a lot."

\begin{tabular}{|l|l|l|l|l|}
\hline $\begin{array}{l}\text { Strongly } \\
\text { Disagree }\end{array}$ & Disagree & ModerateAgree & $\begin{array}{l}\text { Strongly } \\
\text { Agree }\end{array}$ \\
\hline $1.25 \%$ & $5 \%$ & $17.5 \%$ & $66.25 \%$ & $10 \%$ \\
\hline
\end{tabular}

From the below table, focusing on whether students fostered other ability especially communicative ability, it was found that $50 \%$ of students agreed that doing listening tasks helped them have a deeper understanding of western culture, and $7.5 \%$ of students strongly agreed that doing listening tasks helped them enhance the understanding of western culture, which indicated that more than half of the students developed other abilities, not just listening ability.

Table 2. "Doing listening tasks can help me enhance the understanding of western culture."

\begin{tabular}{|l|l|l|l|l|}
\hline $\begin{array}{l}\text { Strongly } \\
\text { Disagree }\end{array}$ & Disagree & Moderate & Agree & $\begin{array}{l}\text { Strongly } \\
\text { Agree }\end{array}$ \\
\hline O\% & $8.75 \%$ & $33.75 \%$ & $50 \%$ & $7.5 \%$ \\
\hline
\end{tabular}

In addition, students became more active in class because the atmosphere in class made them more confident and they were motivated strongly. From the below table, we found that $57.5 \%$ of students agreed that the atmosphere of TBLT in class could enhance their confidence and sense of belonging. $12.5 \%$ of students strongly believed this idea, too. This might be due to the stress-free learning environment in class.

Table 3. "The atmosphere of TBLT in class can enhance my confidence and sense of belonging."

\begin{tabular}{|l|l|l|l|l|}
\hline $\begin{array}{l}\text { Strongly } \\
\text { Disagree }\end{array}$ & Disagree & Moderate & Agree & $\begin{array}{l}\text { Strongly } \\
\text { Agree }\end{array}$ \\
\hline $1.25 \%$ & $3.75 \%$ & $25 \%$ & $57.5 \%$ & $12.5 \%$ \\
\hline
\end{tabular}

Furthermore, task activities motivated students to learn English listening willingly not only in class but also after class. According to the data, $42.5 \%$ of students agreed that they studied English listening after class and $38.75 \%$ of students strongly believed that they practiced English listening after class, which indicated that a majority of students activated their learning motivation of studying English listening by doing tasks in class. The chosen items, the number of each item the students choose, and the percentage in the thirteenth question are in Table 4. 
Table 4. "You take the initiative to practice English listening after class."

\begin{tabular}{|l|l|l|l|l|}
\hline $\begin{array}{l}\text { Strongly } \\
\text { Disagree }\end{array}$ & Disagree & Moderate & Agree & $\begin{array}{l}\text { Strongly } \\
\text { Agree }\end{array}$ \\
\hline $\mathrm{O} \%$ & $7.5 \%$ & $11.5 \%$ & $42.5 \%$ & $38.75 \%$ \\
\hline
\end{tabular}

In section five, the last question in the questionnaire is about students' suggestions on English listening teaching and the improvement of the TBLT classroom. Many students suggested that teachers should design and assign more elaborate tasks to students and let them do more listening exercises. Besides, the types of listening materials could be richer and they can get more information about culture, history, news, and business.

\section{CONCLUSION}

Based on the investigation and analysis of the application of TBLT in listening classes for college English majors, the results revealed that the majority of the students argued that TBLT could improve their English listening ability and recognized this kind of pedagogy to a large extent. To be more specific, students can get more knowledge in class and the learning atmosphere facilitates their learning process. Also, TBLT can not only improve their listening competence but also other competence. For example, they can learn more knowledge about culture when they have done tasks. Additionally, students became more active in class. This is because the atmosphere in class can enhance their confidence and sense of belonging. In the end, the learning motivation of students is activated and students are more willing to do listening exercises after class, compared with the previous situation. The author also investigated students' bits of advice on how to further improve classroom teaching with TBLT. Students recommended that teachers should design more listening tasks and let students do them in class and diversify the listening materials, to emulate actual real scenarios.

It is hoped that the study could contribute to an empirical analysis of the application of TBLT in English listening teaching. However, this study suffers from some limitations. First of all, the number of participates and the range of ages and gender are relatively small. Also, quasi-experimental research designs might be a good choice to investigate the results accurately. Then, there is no qualitative research in the study, and interview, as well as observational survey, can be applied in the future. Thus, I hope more research can be needed in the future.

\section{REFERENCES}

[1] Prabhu, N.S. (1987). Second Language Pedagogy. Oxford: OUP.
[2] Skehan, P. (1998). Task-based Instruction. Annual Review of Applied Linguistics, 18: 268-286.

[3] Richards and Rodgers. (2001). Approach and Methods in Language Teaching. Cambridge University Press.

[4] Ellis, R. (2009). Task-based Language Learning and Teaching. Oxford University Press.

[5] Jeon, I. J., \& Hahn, J. W. (2006). Exploring EFL teachers' perceptions of task-based language teaching: A case study of Korean secondary school classroom practice. Asian EFL Journal, 8(1), 8.

[6] Van den Branden, K. (Ed.). (2006). Task-based language education: From theory to practice. Cambridge University Press.

[7] Norris, J. (2009). The Handbook of Language Teaching. Blackwell.

[8] Nunan, D. (2012). Language Teaching Methodology: A Textbook for Teachers. Cambridge University Press.

[9] Nunan, D. (1989). Designing Tasks for the Communicative Classroom. Cambridge University Press.

[10] Zan Mao. (2012). The Application of Task-based Language Teaching to English Reading Classroom. Theory and Practice in Language Studies, Vol. 2, No. 11, pp. 2430-2438.

[11] Shijun Chen \& Jing Wang. (2019). Effects of Taskbased Language Teaching (TBLT) Approach and Language Assessment on Students' Competences in Intensive Reading Course English Language Teaching. English Language Teaching. Vol. 12, No. 3, pp. 119-138.

[12] Yilin Huang \& Sohani Gandhioke. (2021). A Study Focusing on Applying Task-Based Language Teaching (TBLT) Methods into English Vocabulary Teaching for EFL Learners. International Journal of Higher Education Management (IJHEM), Vol. 8, No. 1., pp. 69-76.

[13] Mu-Hsuan Chou. (2016). A Task-based Language Teaching Approach to Developing Metacognitive Strategies for Listening Comprehension. The International Journal of Listening, 00: 1-20.

[14] Danyan Huang. (2016). Language Teaching Method in a Comprehensive English Class in China. Journal of Language Teaching and Research, Vol. 7, No. 1, pp. 118-127. 